\author{
Jerzy Sierociuk \\ Adam Mickiewicz University in Poznań \\ Institute of Polish Philology \\ ORCID: 0000-0001-9069-6117; e-mail: jasier@amu.edu.pl
}

\title{
About certain dependence of word formation on the structure of the lexical and semantic field
}

\begin{abstract}
This article presents the situation caused by the interference of new lexical units foreign to a specific dialect. Words transparent with respect to word formation, like grabisko, siekierzysko, kosisko, stylisko, documenting the idiom of the formant -isko with the noun base (in names of the components of simple tools) change their characteristics under the influence of an increasingly popular form like styl 'handle'. Consequently, the structure of the type kosisko 'handle, hilt, grips of a scythe' (with a noun basis) is being replaced by the type kosisko 'the metal part of a scythe, the chine' (with a verb basis). Similar transformations are taking place with grabisko.
\end{abstract}

Key words: dialect, word formation in dialects, impact of new lexemes on the word forming structure.

\begin{abstract}
Abstrakt: O pewnej zależności słowotwórstwa od struktury pola leksykalno-semantycznego. W artykule rozpatrzona została sytuacja wywołana ingerencją nowych, obcych konkretnej gwarze jednostek leksykalnych. Przejrzyste słowotwórczo wyrazy typu grabisko, siekierzysko, kosisko, stylisko dokumentujące łączliwość formantu -isko z podstawą rzeczownikową - w kategorii nazw części składowych prostych narzędzi - zmieniają swoją charakterystykę pod wpływem oddziaływania upowszechniającej się formy typu styl 'trzonek'. W konsekwencji zamiast struktury typu kosisko ‘trzonek, rękojeść kosy’ (z podstawą rzeczownikową) zaczyna dominować typ kosisko 'metalowa część kosy, która kosi' (z podstawą czasownikową). Podobne przeobrażeniom poddaje się także grabisko.
\end{abstract}

Słowa kluczowe: gwara, słowotwórstwo w gwarach, oddziaływanie nowych leksemów na budowę struktury słowotwórczej.

Dialectological material, located in time and space, oftentimes offers possibilities of observing complex processes taking place in a live language spoken by a large group of users. It is also an opportunity to follow natural processes, self-regulated only internally within a distinctly outlined territory.

When discussing the processes taking place in a dialectal environment, we need to bear in mind the language's specificity: as forms of oral culture, dialects do not have a normative approach enjoyed by various grammars in the case of standard, written inflection. The feature, of importance to us, has been emphasized by Z. Topolińska: 
In every historical section, the ever so dynamic relation between a local dialect and the standard, creates an entire range of transition forms which are sometimes hard to define theoretically and sometimes it is simply impossible to separate them empirically and describe. In this situation, in my opinion a demarcation line should be drawn wherever it can be drawn and, instead of the dialect $\sim$ standard opposition, we should discuss an opposition between uncontrolled and controlled development (and the development product). When discussing development and the controlled system, I do not mean the self-regulating usage norm i.e. spontaneous control kept by a community using a specific system, but rather control imposed by the local authorities' linguistic policy (typically the government), an administratively enforced prescriptive norm (Topolińska 1992, 251).

In this article, I focus on an attempt to explain the changes taking place in the formant semantics and caused by the properties of the respective lexical and semantic structures. In this specific case, the phenomenon revolves mainly around changes to the formant -isko confirmed in the meaning 'hilt, handle of a simple tool'; therefore, I will take into consideration structures like toporzysko 'handle of an axe or a cleaver', kosisko 'handle of a scythe, grips', grabisko 'handle of rakes' etc.

The major thesis of this article can be presented as follows: semantic characteristics (also the category value) of a formant can be affected by the mutual relations taking place inside a lexical and semantic micro field containing words formed by means of a specific formant. In this specific case, the phenomenon at play are semantic changes of the -isko formant from 'hilt, handle of a simple tool' to 'the part of a simple tool which does the work'. In my opinion, this change has been impacted by an extended lexical structure; in other words, under the influence of superfluous opulence (some sort of lexical surplus), a possible expression restricted to the semantic formant by means of vocabulary.

Let me proceed to the heart of the matter.

The tools I discuss here consist of two parts: a type of a long stick connected with the part used to complete a task. These two parts of specific tools can be referred to by very different words. The longer parts, hand-held, are typically derivatives with -isko; the "working" parts have names either identical with the entire tool - e.g. scythe, or names unrelated to a specific tool, e.g. belka or prożek (próg) as a part of a rake (grabie). Therefore, with respect to the assortment of lexical elements required to describe specific referents, there are two groups: tools whose total names are the same as their elements, e.g. kosa as 'a tool for scything' but also 'the metal part of a scythe'; siekiera is 'a tool to chop' and 'a metal part of an axe'. On the other hand, there are tools like grabie (rake) consisting of a grabisko and a belka (beleczka, próg) and cepy (flail) which is a combination of a dzierżak and a bijak.

As I am going to present an analysis of names related to the construction of a scythe and a rake, it is advisable to show their diverse names in Polish dialects. However, earlier I will refer to F. Sławski's opinion which provides a historical background for these considerations:

The major function of the suffixes -išče, -isko is creating loci nominatives from the basic nouns or verbs, e.g. bělišče : bělisko 'a place where cloth is whitewashed' < běliti 'whitewash, bleach, for example cloth' (Sławski 1974: 95). 
He continues by stating:

A group of words with these suffixes meaning 'a tool's handle' is also well confirmed, e.g. kosišče : kosisko 'a snaith of a scythe' < kosa; sekyrišče : sekyrisko 'a handle of an axe' < sekyra 'siekiera' (axe); toporišče : toporisko 'a battle-axe's handle' < toporb 'topór' (Sławski 1974, 96).

Contemporary dialects in fact continue the Proto-Slavic status; this is the latest distribution of the words in question:

The names of the handle of a digging fork clearly vary from one area to another. With the exception of several sporadically recorded names which are always duplets (...), there are four etymological groups of the different names. They are: trzonek (trzon); widlisko; stylisko (styl) and raczka, the latter having a very small range but clearly focused geographically. Once the diversity of the word-formation and the lexicalised phonetics have been considered, we obtain in total 9 names indicating the handle of a digging fork (Basara 1997, 63).

The handle of a digging fork - beside the systemic phonetic changes - is referred to as grabisko all over Poland (...) (Basara 1997, 64).

The nomenclature for the snaith of a scythe is almost homogenous. All the dialects use the word kosisko (...) (Basara 1997, 65).

While the names of a rake as an entire tool and the end of a rake (...) including the teeth of a rake, are poorly geographically diversified, the word for the stick attached to the teeth is extremely diverse and interestingly distributed in the field (Basara, Basara 2004, 163).

The above references and the distribution of the names on the specific linguistic maps create an impression that the material of interest is poorly diversified while the names are basically clear. Dialectological maps show another aspect of the issue: there are references to only one name in the specific survey points. Less experienced readers of these maps (and dialectologists are of an opinion that map reading is a useful skill) might think that only the indicated name is in fact, if not exclusively, used in a specific location. Disregarding other details characteristic of dialectological research, this is a case of lexical typicality, lack of alternations etc. Lexical diversity, so common on dialectological maps, cannot serve as an argument in favour of a high degree of synonymy of dialectal vocabulary (Sierociuk 2001); dialects avoid expanded synonymy.

An analysis of the lexicographic documentation contained in dictionaries and maps provides an unambiguous picture: in a lexical and semantic field referring to simple tools, -isko forms the names of the tools' handles.

This is why, especially in Wielkopolska, the following words may pop up in conversations: 
1. Czaczyk, Kościan county (southern Wielkopolska); informant: female, born in 1933:

Q: Jak mówimy na plaską, metalową część kosy?

A: kosisko? ...

Q: Ta część kosy, która tnie.

A: to to kosisko ...

After some time, further in the conversation:

Q: A dluga, drewniana część kosy?

A: kosisko ...

2. Palędzie, Poznań county (central Wielkopolska); informant: male, born in 1952:

\section{Q: $\mathbf{Z}$ jakich części zbudowane są grabie?}

A: grabie ... no to so $o^{m}$ zes trzonka $i$... i z grabiska ... to jes to grabisko ... tag mówiliy ... ja to mówie ta-ag u mnie $w$ domu mówili ... nie $e^{l}$... to jes to grabisko ... to jes to ... i tu som drewnianne zem $e^{m}$... a tu jes trzonek ... nie ...

Q: A czy jest jakiś element metalowy?

A: dawni $w$ grabiach to nie byto ...

Q: Ta część grabi, która się trzyma w reku?

A: trzonek ... to tag mówili zawsze ...

Q: A ta część, która się grabi?

A: no tag mówili grabisko ... nie ... bo ja wim co to jeszcze? ...

3. Giżyce, Ostrzeszów county (south-eastern Wielkopolska); informant: male, born in 1942:

Q: Część grabi, którą trzyma się w ręku?

A: no to ... sztyl ... sztyl ...

Q: A ta część grabiąca?

A: no ... to-s ... no to jes grabisko ... grabisko ...

4. Bukowiec Górny, Leszno county (western Wielkopolska);

a. informant: male born in 1922

Q: Ta część cepy, którą trzyma się w rękach, to długie.

A: jak ... to nawed nie wim ... a to but ... cepisko ... a to but bijok ... a tutyj byty kapa ... co to ... skórzane niby takie buto ...

Q: Czyli cepisko to był ten długi, kij?

A: tak ... tyn kij to buto cepisko ... ta oprawa ...

Q: A to narzędzie, którym się grabi?

A: to grabie przeciż ...

${ }^{1}$ In Wielkopolska dialects, nie is often used as the colloquial no (emphatic for yes). 
Q: Część grabi, którą się trzyma w rękach.

MaF: śtylisko (!) ... styl ...

Q: A ta część grabi, w której są zęby?

A: to grabisko ... no ...

Q: Czyli zęby były w grabisku, tak?

A: $\operatorname{tak} \ldots$

b. informant: female born in 1968

A: ... kosa wiem jag wygon ${ }^{n}$ a ...

Q: Jakie fragmenty wyodrębnia się w metalowej części kosy?

A: kosisko ...

Q: A co to jest kosisko?

A: kosisko to jes chyba właśnie ta cze źdź metalowa która ścina ... nie wiem ... trawe ... zboże ...

Q: Czyli to jest ta całość metalowa, czy tylko któryś fragment?

A: no ... dla mnie to jakiś ten ...

Q: To drewniane, tak?

A: to ja nie wiem ... to ja nie wiem ... bo mi sie wydaje że kosisko to ta cze śś która kosi ... ale nie jestem pewna ...

The above examples show that the phenomenon is not limited to a small area, to a dialect spoken in a single village. Similarly, the examples do not come from only selected inhabitants. Of importance to this analysis is the fact that these confirmations come from interlocutors representing various generations, most typically a younger part of the rural population. Nevertheless, the phenomenon itself deserves a close scrutiny.

It seems that in an attempt to explain the above examples, a reference must be made to the general characteristics of the occurrence of the formant -isko in Polish dialects. Researchers should not only examine the presence of the formant in question but also its general productivity. For the purpose of this article, I have considered material from two areas of different dialectal affiliation: the Lublin region and Wielkopolska.

Bearing in mind the general, category-related characteristics, there are hardly any differences. In the dialects of both dialectal complexes, -isko is used to form names of places, augmentative names and handles of simple tools. In both areas, there are occurrences of owsisko 'a field where oats grew'; psisko 'a large dog; pejoratively about a dog'; grabisko 'a handle of a rake'. There are also bases conditioned by the differences in the lexical exponents like: kartoflisko and pyrczysko referring to 'a field where potatoes grew i.e. pyry (in Wielkopolska)'. The differences come up only when we juxtapose replies to questions about identical referents: in both areas under scrutiny, 'a handle of an axe' is called toporzysko. However, in the Lublin region the expected (and in Wielkopolska confirmed) form toporzysko was not recorded. In the Lublin region, 'an old, shabby overcoat' is fartuszyna, by analogy with sukienczyna. The dialects spoken in southern Wielkopolska confirm fartuszysko and sukienczysko used in this semantic context. 
Field research often proves that within the same category of meaning, a specific formant can be used in various geographic complexes depending on the basis with which it forms a word. Therefore, dialectology is more focused on the range of a specific derivative than the general range of the formant used in that derivative. To some extent, these expectations (i.e. the range of a formant and the range of a derivative) are reconciled in collective maps which show the productivity of a specific word-forming unit (Kowalska 1991).

Of more interest is the difference in productivity of the formant -isko in the two regions where Wielkopolska confirms a wider use. It is not possible to refer to the ample material available; let me only emphasize that in the context of the Lublin confirmations, the locative kupowisko recorded in Wielkopolska (Bytyń, Szamotuły county - western Wielkopolska; informant: female born in 1941: śmietnisko to jes kupowisko wielkie ... nie ${ }^{1}$... a śmietnig no to jez mniejsze ... nie ...). Compared with the material collected in the Lublin region, this is a slightly different arrangement of semantic relations within a specific formant defined as a cluster of semantic relations. A juxtaposition of the materials obtained in both areas shows that in the dialects spoken in the Lublin area, the semantic distinction of the formant -isko is more definite than in Wielkopolska.

The extended meaning of the category-related formant -isko is coupled with synonymy foreign to dialects; the typical word-forming structure has been replaced by a borrowed element, the German sztyl, confirmed in various phonetic variants. The unit "competes" with the native elements. Sztyl has taken over the meaning of all the local names of handles. This is clearly confirmed by field material:

5. Bukówiec Górny, Leszno county (western Wielkopolska); informant: female born in 1923:

Q: Co to jest sztyl; przy jakich narzędziach sztyl występuje?

A: styl to jes przy topacie ... przy siekirze ... przy szczotce do zamiatania ...

Q: Przy czym jeszcze może być sztyl?

A: no mówie ... przy grabiach ... przy hakach ...

Q: Przy grabiach też jest sztyl?

A: tyzi styl ...

A przy kosie?

A: $t y \dot{z} \ldots$

Q: Czyli mówilo się, że trzeba było grabie ...

A: oprawidź na sztyl ... na styl ...

Q: A co to $\mathrm{w}$ takim razie ...

A: na ten ... na ... na kosie to kosisko ... oprawa ... kosisko ...

Q: To nie sztyl tylko kosisko?

A: kosisko ...

Q: A przy grabiach?

A: sztyl ...

Q: A z jakich części cepa się składała? 
A: cepa sie sktadała ... ta-ag by wateg do ... do watkowania ... z drywna ... nie ... i śtyl ... cepisko mówili ... cepisko ... i na ... na takich paskach ... uhaczóne ze skóry ...

Q: I jak te poszczególne części byly nazywane; cepisko to ta część krótsza czy dłuższa; czym się trzymało czy czym się uderzało?

A: czym sie uderzato ...

Q: To cepisko?

A: no ... cepisko ...

Q: A to, co się w rękach trzymało?

A: no to chyba styl ... bo co je ... bo to re ${ }^{n}$ ce ...

Introduction of a new and very expansive unit to a lexical and semantic structure consisting of few units distorts the structure. The above examples are unambiguous evidence of the scenario.

Notably, the presented semantic fluctuations are typical of Wielkopolska dialects; the Lublin area with its clear arrangement of -handle : word-forming type with -isko - does not have the problem.

Therefore, how do we explain the semantic shift present in the dialects spoken in southern Wielkopolska in the meaning-related structure of the formant -isko, a formant also commonly recognised in the general Polish language?

Observations of other specific cases recorded during field research indicate the consequence of interfering with a stable lexical and semantic structure. Interestingly, the indicated semantic disturbance pertains in fact to two words: kosisko and grabisko. The emergence of the prevailing type sztyl has weakened the semantic distinctiveness of the formant -isko which in these words starts to be combined with the bases of verbs. Therefore, this is a case of neutralizing the basic meaning of 'handle...' and the resulting different genetic perception of these derivatives. In the new reality, they are perceived as adverbial structures while the stabilising category-related meaning is: 'a part of a simple tool which does ... (an activity indicated in the basis)'.

In the course of an analysis of the above indicated phenomena, a question arises about their range. Is this a peculiarity confirmed only by this example?

Dialectological material offers examples of surprising consequences which are an attempt to bring order to linguistic reality. In the dialects spoken in the Lublin region, 'a mushroom which has mucus (like butter - masto)' is referred to as maślak or maśluch. In the zone where the two names coexist, a structure has emerged which is undoubtedly a result of morphological contamination: maślach (Sierociuk 1996, map 30). However, in areas located on the outskirts of dense ranges of the specific word-forming types, the type maśloch has been recorded. Notably, the type maśloch cannot be perceived as an effect of the so-called inclination, a feature characteristic of dialects in large parts of Poland. This interpretation is corroborated by the position against the "competing" units of language. Therefore, the density on the morphological level has resulted in an emergence of a "resultant" form from the phonological level. Competition, a conflict between forms with a high vowel (maśluch) and a low vowel (maślak) have paved the way for an intermediate form - with a medium vowel (maśloch).

The presented material shows changes to only a single phenomenon; nevertheless, it gives a reason to take a closer look at the relations between word formation and 
vocabulary. This is also an example of a response of the living (spoken) language to problems stemming from an excess of linguistic elements, in this case words. Dialects which do not contain normative depictions handle this lexical surplus very well. Bearing in mid the fact that the standard language is increasingly affected by the informal variant (with a large share of dialects), the phenomenon presented here does not need to be a singular case, limited to dialects*.

\section{Bibliography}

Basara J. (1997), Nazwy trzonków kilku prostych narzędzi rolniczych widlisko, grabisko, kosisko, [in:] Z polszczyzny historycznej $i$ wspótczesnej, T. Ampel (ed.), Rzeszów, pp. 63-69.

Basara A., Basara J. (2004), Nazwy grabi i ich części w gwarach polskich, [in:] Общеславянский лингвистический атлас. Материаль и исследования. 2001-2002. Сборник научных трудов, Москва, pp. 162-170.

Kowalska A. (1991), Podziały językowe Mazowsza na tle podziałów pozajęzykowych, Warszawa.

Kowalska A. (2004), Sufiks -isko w stowiańskich nazwach pól po uprawach (w świetle materiałów Ogólnostowiańskiego atlasu językowego), [in:] Общеславянский лингвистический атлас. Материалы и исследования. 2001-2002. Сборник научных трудов, Москва, pp. 35-49.

Sierociuk J. (1996), Budowa wybranych formacji rzeczownikowych - szczególnie nazw miejsc w gwarach między Wista a Wieprzem, Lublin.

Sierociuk J. (2001), W sprawie synonimii w polszczyźnie ogólnej $i$ w gwarach, [in:] Leksyka i gramatyka $w$ tekście językowym, K. Wojtczuk (ed.), Siedlce, pp. 195-203.

Sierociuk J. (2003), Założenia metodologiczne badań języka wsi, [in:] Poznańskie Spotkania Językoznawcze, vol. XI, Z. Krążyńska and Z. Zagorski (eds.), Poznań, pp. 131-136.

Sławski F. (1974), Zarys stowotwórstwa prastowiańskiego, [in:] Słownik prasłowiański, vol. I, A-B, F. Sławski (ed.), Wrocław-Warszawa-Kraków-Gdańsk, pp. 43-141.

Topolińska Z. (1992), Miejsce dialektologii wśród innych dyscyplin slawistycznych, [in:] Z polskich studiów slawistycznych, series 8, Warszawa, pp. 249-254.

* This is a modified and extended version of the text $O$ pewnej zależności słowotwórstwa od struktury pola leksykalno-semantycznego, [in:] Словообразуване и лексикология. Доклади от Десетата международна конференцияна на Комисията по славянско словообразуване при Международния комитет на славистите. София, 1-6 октомври 2007, В. Радева, Ц. Аврамова, Ю. Балтова (eds.), София 2009, pp. 401-409. 